\title{
Effect of Methotrexate on Intracellular Folate Pools in Purified Myeloid Precursor Cells from Normal Human Bone Marrow
}

\author{
Jacob Baram, Carmen J. Allegra, Robert L. Fine, and Bruce A. Chabner \\ Clinical Pharmacology Branch, Division of Cancer Treatment, National Cancer Institute, Bethesda, Maryland 20892
}

\begin{abstract}
We investigated the effects of the antifolate methotrexate on intracellular folate pools of human myeloid precursor cells (MPCs). Immature MPCs, representing 3.2\% of the original marrow population, were selected from normal human bone marrow by immune rosetting. The intracellular folate pools were labeled by incubation with $\left.5 \times 10^{-8} \mathrm{M}^{3} \mathrm{H}\right] 5$-formyl-FH 4 and were quantitated by high performance liquid chromatography. The predominant folates were 5-methyl-tetrahydrofolate (5methyl-FH ${ }_{4}$ (36\%), 10-formyl-FH 4 (41.4\%), 5-formyl-FH (12.3\%), and $\mathrm{FH}_{4}(10.3 \%)$. A 12-h exposure to $1 \mu \mathrm{M}$ methotrexate (MTX) resulted in a 34\% reduction in the intracellular concentration of 10 -formyl-FH $\mathrm{H}_{4}$, a $61 \%$ decrease in 5-formyl-

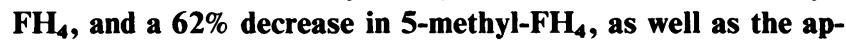
pearance and progressive expansion of the $\mathrm{FH}_{2}$ and 10-formyl$\mathrm{FH}_{2}$ pools. These changes were maximal after $4 \mathrm{~h}$ of incubation with MTX. Paralleling the changes in folates, particularly the increase in $\mathrm{FH}_{2}$, were a $64 \%$ reduction in myeloid colony formation and a 77\% depression of de novo purine synthesis after $4 \mathrm{~h}$ of MTX. We conclude that MTX does not produce quantitative depletion of 10 -formyl-FH $\mathrm{F}_{4}$ and that its antipurine effect may be mediated by direct inhibition of de novo purine synthesis by $\mathrm{FH}_{2}$ and, at later time points, by MTX polyglutamates.
\end{abstract}

\section{Introduction}

Methotrexate (2,4-diamino,10-methylpteroyl glutamic acid; MTX $)^{1}$ is a tight-binding inhibitor of dihydrofolate reductase (DHFR) and has shown potent antitumor activity against human leukemia, non-Hodgkin's lymphoma, choriocarcinoma, and other human tumors (1). Its primary toxic effects are myelosuppression and mucositis. Its antineoplastic effect as well as toxicity have been ascribed to depletion of reduced folates with consequent arrest in the synthesis of purines, thymidylate, and proteins. However, significant depletion of reduced folate pools after MTX treatment has not been demonstrated in tissue culture (2) or in vivo.

An alternative explanation for inhibition of purine and pyrimidine biosynthesis has been forthcoming from studies of the properties of the polyglutamated forms of MTX and dihydrofolate $\left(\mathrm{FH}_{2}\right)$, which accumulate intracellularly during MTX ex-

Received for publication 2 June 1986.

1. Abbreviations used in this paper: AICAR, aminoimidazolecarboxamide ribonucleotide; CFU-C, colony-forming units in culture; DHFR, dihydrofolate reductase; $\mathrm{FH}_{2}$, dihydrofolate; $\mathrm{FH}_{4}$, tetrahydrofolate; MEM, minimal essential medium; MNC, mononuclear cell; MPCs, myeloid precursor cells; MTX, methotrexate; SRBC, sheep erythrocyte.

The Journal of Clinical Investigation, Inc.

Volume 79, March 1987, 692-697 posure. Polyglutamated MTX as well as dihydrofolate pentaglutamate have a direct inhibitory effect on thymidylate synthase $(3,4)$ and aminoimidazolecarboxamide ribonucleotide (AICAR) transformylase (5), the key folate-dependent enzymes in the synthesis of thymidylate and purines, respectively.

Evidence in support of this alternative explanation of MTX action has been forthcoming from direct measurement of the folate pools in MCF-7 breast cancer cells, accomplished by labeling the intracellular folates with $\left[{ }^{3} \mathrm{H}\right]$ folic acid, followed by separation of individual folates by high performance liquid chromatography (HPLC). Exposure of these cells to $1 \mu \mathrm{M}$ MTX resulted in marked inhibition of de novo purine synthesis despite only $20 \%$ depletion of 10 -formyl-tetrahydrofolate (10-formyl$\mathrm{FH}_{4}$ ), the substrate required for purine biosynthesis. The authors suggested that the purine biosynthetic pathway was directly inhibited by MTX and/or $\mathrm{FH}_{2}$ polyglutamates.

To determine the effects of MTX on intracellular folates in these cells, we have isolated an immature fraction of marrow cells by immune rosetting. The immature fraction thus obtained was composed of $80 \%$ myeloblasts, promyelocytes, and myelocytes (the dividing population of marrow myeloid lineage). The following study demonstrates relative preservation of the 10 formyl- $\mathrm{FH}_{4}$ pool in the presence of concentrations of MTX that were cytotoxic to myeloid colony formation. At the same time, MTX exposure led to significant expansion of pools of $\mathrm{FH}_{2}$, and the appearance of a new folate compound, 10-formyl- $\mathrm{FH}_{2}$.

\section{Methods}

Chemicals. MTX was obtained from the Drug Synthesis and Chemistry Branch, National Cancer Institute (Bethesda, MD) and was purified by DEAE-Sephacel chromatography as previously described (6). [3',5',7,9${ }^{3} \mathrm{H}$ - $-\mathrm{l}-5$-Formyl- $\mathrm{H}_{4}-\mathrm{PteGlu}$ (specific activity, $1 \mathrm{Ci} / \mathrm{mmol}$ ) was synthesized from $\left[3^{\prime}, 5^{\prime}, 7,9-{ }^{3} \mathrm{H}\right]$ PteGlu according to the methods of Moran et al. (7). Hog kidney polyglutamate hydrolase (13-15 $\mathrm{mg}$ protein/ml) was prepared according to the method of McMartin et al. (8). Folate-free RPMI-1640 medium was obtained from the National Institutes of Health Media Unit (Bethesda, MD). Eagle's minimal essential medium (MEM) and phosphate-buffered saline (PBS) (pH 7.4) were purchased from M. A. Bioproducts (Walkersville, MD). Agar (BactoAgar) and fetal calf serum (FCS) were purchased from Difco Laboratories Inc. (Detroit, MI). FCS was heat-inactivated at $56^{\circ} \mathrm{C}$ for $30 \mathrm{~min}$, followed by extensive dialysis to remove nucleosides and folates. Colony-stimulating factor prepared from conditioned medium of the MO cell line, a T-cell variant of hairy cell leukemia $(9,10)$, was provided by Dr. D. W. Golde, UCLA School of Medicine (Los Angeles, CA). Pooled human AB serum was obtained from the National Institutes of Health Blood Bank (Bethesda, MD), and sheep erythrocytes (SRBCs) were obtained from the National Institutes of Health Animal Center (Rockville, MD). Monoclonal antibodies OKT3, B1, and M3 were purchased from Ortho Pharmaceutical Corp. (Raritan, NJ), Coulter Immunology (Hialeah, FL), and Becton Dickinson Monoclonal Center Inc. (Mountain View, CA), respectively. MY8 $(11,12)$ was provided by Dr. J. Griffin, Dana-Farber Cancer Institute (Boston, MA) and EP1 (13) by Dr. T. Papayannopoulou, University of Washington 
(Seattle, WA). Affinity-purified goat anti-rabbit IgG [F(ab $)_{2}$ fragmentspecific] antibody was obtained from Cappel Laboratories (Malvern, PA) and extensively dialyzed against $0.15 \mathrm{M}$ borate-buffered saline (pH 7.4). The $\mathrm{F}(\mathrm{ab})_{2}$ fragment of rabbit anti-mouse Ig (IgG + IgA + IgM) was purchased from Zymal Laboratory Inc. (San Francisco, CA).

Purification of myeloid precursor cells (MPCs). After obtaining informed consent, heparinized bone marrow samples were collected by aspiration from the posterior iliac crest of normal volunteers. The mononuclear cell (MNC) population was separated by Ficoll-Hypaque gradient centrifugation. A fraction enriched in myeloid precursor cells was obtained by an affinity rosetting technique, as described previously $(12,14$, 15). Briefly, SRBCs were coupled with goat anti-rabbit $\operatorname{IgG}\left[\mathrm{F}(\mathrm{ab})_{2}\right.$ fragment-specific] by the chromium chloride technique and reacted with the $\mathrm{F}(\mathrm{ab})_{2}$ fragment of rabbit anti-mouse $\mathrm{Ig}(\mathrm{IgG}+\mathrm{IgA}+\mathrm{IgM})$-specific antibody. Bone marrow MNCs $\left(0.5-1.0 \times 10^{8} / \mathrm{ml}\right)$ were incubated in MEM containing $2.5 \%$ human AB serum (MEM-AB) with a mixture of monoclonal antibodies-OKT3, B1, and M3 at a final dilution of 1:200, MY8 (1:100), and EP1 (1:500)-and allowed to rosette with a 10\% suspension of Ig-coated SRBCs. The nonrosetted cells (antibody negative) were separated from the rosetted cells by Ficoll-Hypaque gradient centrifugation, collected from the interface, washed, and red cells were lysed by incubation in $1 \mathrm{ml}$ ice-cold hypotonic buffer $\left(0.17 \mathrm{M} \mathrm{NH}_{4} \mathrm{Cl}, 0.01\right.$ $\mathrm{M} \cdot \mathrm{KHCO}_{3}$, and $0.0001 \mathrm{M}$ EDTA) for $5 \mathrm{~min}$. The cells were counted with a hemacytometer and their viability assessed by trypan blue exclusion. $2-6 \times 10^{6}$ cells, i.e., $3.2 \pm 1.1 \%$ of the original mononuclear cell population of the marrow were recovered in the final purified fraction and $>95 \%$ were viable as assessed by trypan blue exclusion.

Quantitation of intracellular folate pools. The purified MPCs (1-2 $\times 10^{6} \mathrm{cells} / \mathrm{ml}$ ) were incubated at $37^{\circ} \mathrm{C}$ in folate-free RPMI- 1640 with $10 \%$ dialyzed FCS, 2 mM L-glutamine, and $\left[3^{\prime}, 5^{\prime}, 7,9-{ }^{3} \mathrm{H}\right]-l-5$-formyl-FH $4_{-}$ PteGlu (specific activity, $1 \mathrm{Ci} / \mathrm{mmol}$ and final concentration $5 \times 10^{-8}$ M) for $24 \mathrm{~h}$. Equilibration of radiolabeled 5-formyl-FH, with intracellular folate pools was reached at $12-16 \mathrm{~h}$ as determined by a constant level of ${ }^{3} \mathrm{H}$-label in each pool and a constant proportional distribution of the ${ }^{3} \mathrm{H}$-label among the various peaks of the intracellular folate pools thereafter (data not shown). Neither breakdown of the tritiated 5-formyl-FH in the medium nor a decrease in the cell viability, as determined by trypan blue exclusion, was noted during the incubation period. In a preliminary study, equilibration was not achieved when the immature myeloid cells were incubated with $\left[{ }^{3} \mathrm{H}\right]$ folic acid for up to $36 \mathrm{~h}$ under similar conditions. The total uptake of $\left[{ }^{3} \mathrm{H}\right]$ folic acid was low and the total intracellular ${ }^{3} \mathrm{H}$-label continued to increase after $36 \mathrm{~h}$, although the relative distribution of ${ }^{3} \mathrm{H}$-label among the various intracellular pools was comparable to that found after incubation of cells with $\left[{ }^{3} \mathrm{H}\right] 5$-formyl$\mathrm{FH}_{4}$, with the exception of the intracellular $\left[{ }^{3} \mathrm{H}\right]$ folic acid pool, which increased constantly over this time period. Although it may have been possible to reach a plateau by longer incubation (beyond $36 \mathrm{~h}$ ) with $\left[{ }^{3} \mathrm{H}\right]$ folic acid, extended periods of incubation led to a decrease in viability of the myeloid precursor population. Therefore, $\left[{ }^{3} \mathrm{H}\right] 5-$ formyl- $-\mathrm{FH}_{4}$ was used to label the intracellular folates.

After a 24-h preincubation of purified myeloid precursors with $\left[{ }^{3} \mathrm{H}\right] 5$ formyl- $\mathrm{FH}_{4}, \mathrm{MTX}$ was added at various concentrations and for various durations according to the particular experiment. After incubation with the drug, the MPCs were washed three times in ice-cold PBS and resuspended in $1 \mathrm{ml}$ PBS. A 50- $\mu$ l portion was diluted in $750 \mu \mathrm{l}$ PBS, sonicated, and the protein quantitated by the Biorad microassay method (16). 2 $\mathrm{ml}$ of a solution containing $2 \% 2$-mercaptoethanol and $2 \%$ ascorbate and adjusted to $\mathrm{pH} 6$ was added to the remaining part of the sample $(950 \mu \mathrm{l})$ and boiled for $90 \mathrm{~s}$. The supernate was then treated with partially purified hog kidney polyglutamate hydrolase $(1 \mathrm{ml})$ for $30 \mathrm{~min}$ at $37^{\circ} \mathrm{C}$ and was subjected to an additional 90 -s boil after the further addition of $2 \mathrm{ml}$ of the 2-mercaptoethanol, ascorbate solution. The denatured protein was pelleted by centrifugation at $2,000 \mathrm{~g}$ for $10 \mathrm{~min}$ and the folates contained in the supernate were extracted into a methanol phase, using a $C_{18}$ Sep-Pak cartridge. The labeled folates were separated by reverse-phase HPLC on a $\mathrm{C}_{18}$ Bondapak column, as previously described (2), and quantitated by liquid scintillation counting of the fractions collected from the HPLC. The mobile phase for HPLC separation consisted of $85 \%$ Pic Reagent A (at either pH 7.4, 5.5) and 15\% methanol, and compounds were eluted using isocratic conditions and a flow of 2 $\mathrm{ml} / \mathrm{min}$.

The proportion of intracellular folate found as a monoglutamate or as a polyglutamate was determined by dividing a cell extract, after the initial boiling step, into two samples. In one sample polyglutamates were subjected to hydrolysis by hog kidney conjugase, as described above, while buffer lacking conjugase was added to the second sample. Both samples were then subjected to centrifugation, Sep-Pak fractionation, and HPLC, and the profile of monoglutamate folates was compared for the two samples. Polyglutamated folates are not eluted in the HPLC systems used in these experiments and cannot be quantitated.

Assay of colony-forming units in culture (CFU-C) for MTX cytotoxicity. Aliquots of $2 \times 10^{5}$ purified MPCs were incubated for up to $24 \mathrm{~h}$ in folate-free RPMI-1640 and 10\% dialyzed FCS with 0-10 $\mu \mathrm{M}$ MTX, washed twice in cold PBS, and resuspended in $1 \mathrm{ml}$ of RPMI-1640. The CFU-C assay was performed using a semi-solid agar method $(14,17) .2$ $\times 10^{4}$ cells/plate were cultured in $0.3 \%$ agar in drug-free RPMI- 1640 medium (containing $2.2 \mu \mathrm{M}$ folic acid) supplemented by $15 \%$ dialyzed FCS and 15\% MO colony-stimulating factor. After 10-14 d of incubation at $37^{\circ} \mathrm{C}$ in a humidified atmosphere of $5 \% \mathrm{CO}_{2}$ in air, colonies $(\geq 40$ cells) were counted using an inverted microscope.

Measurements of purine metabolism. The rate of synthesis of purines by the de novo pathway was measured according to the following method: MPCs, $2 \times 10^{6}$ cells in a total volume of $1 \mathrm{ml}$, were incubated at $37^{\circ} \mathrm{C}$ in folate-free RPMI-1640, 10\% dialyzed FCS, and $10 \mu \mathrm{M}$ thymidine, with or without $1 \mu \mathrm{M}$ MTX. $\left[2-{ }^{14} \mathrm{C}\right]$ Glycine was added $2 \mathrm{~h}$ before the end of incubation to final concentration of $0.17 \mathrm{mM}$ and final specific activity of $12 \mathrm{mCi} / \mathrm{mmol}$. The cells were washed three times with $2 \mathrm{ml}$ of cold PBS, followed by final pelleting by centrifugation at $2000 \mathrm{~g}$ for $10 \mathrm{~min}$. Perchloric acid, $0.5 \mathrm{ml}$ of $1 \mathrm{~N}$, was added to the cell pellet and the precipitated macromolecules were depurinated by boiling for $1 \mathrm{~h}$. After depurination, the supernate was neutralized with $1 \mathrm{~N} \mathrm{KOH}$ and the adenine and guanine bases separated by reverse-phase HPLC and quantitated by liquid scintillation counting of the separated fractions as previously described (18).

\section{Results}

Myeloid precursor cell enrichment. Mononuclear cells were exposed to mouse monoclonal antibodies specific for each cell subpopulation except immature myeloid precursors and the antibody-coated cells were reacted with rabbit anti-mouse Ig-coated SRBCs. The final cell population collected after removal of the immune rosettes consisted of $2-6 \times 10^{6}$ cells, which constituted an average of $3.2 \pm 1.1 \%$ of the mononuclear cells in the original marrow sample. The purified population included $61 \pm 17 \%$ blasts, $6 \pm 5 \%$ promyelocytes, and $13 \pm 10 \%$ myelocytes. Additional cells were metamyelocytes and granulocytes (14\%), monocytes (2\%), lymphocytes (2\%), and normoblasts (2\%). In three representative experiments, this procedure led to an increase in cloning efficiency in the CFU-C assay from $43.7 \pm 11.8$ to $414 \pm 73$ colonies per $10^{5}$ plated cells, i.e., a 9.5 -fold increase. Folate pools were measured in this enriched cell population.

Intracellular folate pool measurements. The MPCs were incubated in folate-free RPMI supplemented with $10 \%$ dialyzed FCS and $0.05 \mu \mathrm{M}\left[{ }^{3} \mathrm{H}\right] 5$-formyl- $\mathrm{FH}_{4}$ for $24 \mathrm{~h}$. The uptake of radiolabeled folate reached an equilibrium at 12-16 h; at this time, total intracellular folate pools were $20.3 \pm 2.1 \mathrm{pmol} / \mathrm{mg}$ cytosol protein. After removal of cells from medium containing $\left[{ }^{3} \mathrm{H}\right] 5$-formyl- $\mathrm{FH}_{4}$ and their resuspension in RPMI containing no folate, $92 \%$ of the labeled intracellular folate pool remained at $8 \mathrm{~h}$, and its proportional distribution among the specific cofactors remained unchanged. In control cells, $20 \%$ of the intracellular folates were in a monoglutamate form. Only reduced 
folates were identified in measurable quantities in cells not exposed to MTX. The major cofactors were 10 -formyl-FH $\mathrm{FH}_{4}$ and 5-methyl- $\mathrm{FH}_{4}$, in approximately equal proportions, 41.4 and $36 \%$, respectively (Table I). The remainder of the folates were $\mathrm{FH}_{4}$ and 5-formyl- $\mathrm{FH}_{4}$. 5,10-methylene- $\mathrm{FH}_{4}$ was consistently identified in the bone marrow samples, although its pool size was $<5 \%$ of the total folate pool, and as such its precise quantitation was not possible by these methods.

Effect of MTX on intracellular folate pools. We examined the influence of increasing MTX concentrations on the intracellular folate pools. After equilibration with $5 \times 10^{-8} \mathrm{M}\left[{ }^{3} \mathrm{H}\right] 5$ formyl- $\mathrm{FH}_{4}$ for $24 \mathrm{~h}$, MPCs were exposed to drug for $2 \mathrm{~h}$. Changes were seen after $2 \mathrm{~h}$ at drug concentrations as low as $0.1 \mu \mathrm{M}$. At this MTX concentration, the 5-methyl- $\mathrm{FH}_{4}$ pool decreased by $35 \%$, while two oxidized cofactors, $\mathrm{FH}_{2}$ and 10 formyl- $\mathrm{FH}_{2}$, not present in control samples were clearly identified at this drug level and increased at higher MTX concentrations. After $1 \mu \mathrm{M}$ MTX for $2 \mathrm{~h}$, the $\mathrm{FH}_{2}$ pool constituted $32 \%$ and 10 -formyl- $\mathrm{FH}_{2}$ reached $6 \%$ of the total intracellular folates, while at $10 \mu \mathrm{M} \mathrm{MTX}, \mathrm{FH}_{2}$ represented $27 \%$ and 10 formyl- $\mathrm{FH}_{2}$ represented $11 \%$ of total folates (Fig. 1). The identity of the 10 -formyl- $\mathrm{FH}_{2}$ peak on HPLC was verified by its quantitative conversion to 10 -formyl- $\mathrm{FH}_{4}$ in the presence of DHFR (2) and by its catalytic activity as a substrate for AICAR transformylase.

Increasing the MTX concentration from 0.1 to $1 \mu \mathrm{M}$ for 2 $h$ caused further changes in the reduced folate pools, particularly an additional decrease in 5-methyl- $\mathrm{FH}_{4}$ and a complete disappearance of $\mathrm{FH}_{4}$. In contrast, the pool of 10 -formyl- $\mathrm{FH}_{4}$ was relatively preserved, the maximal decrease to $65 \%$ of the pretreatment level occurring at $1 \mu \mathrm{M}$ MTX. A further increase in MTX concentration to $10 \mu \mathrm{M}$ had little additional effect, except

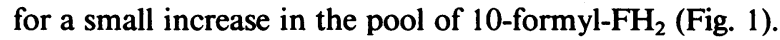

In addition to the changes in intracellular distribution of folates, MTX caused a dose-related decrease in the total intracellular folate content (Table II) to a maximum of $65 \%$ of control $4 \mathrm{~h}$ after exposure to $10 \mu \mathrm{M}$ MTX. The monoglutamated fraction, which constituted $20 \%$ of intracellular folates in control

Table I. Folate Cofactor Pools in Untreated Myeloid Precursor Cells of Normal Bone Marrow

\begin{tabular}{lcc}
\hline Folate cofactor & Fraction of total & Pool size \\
\hline & $\%$ & pmol/mg protein \\
10-Formyl-FH & & $8.4 \pm 1.6$ \\
FH $_{4}$ & 41.4 & $2.1 \pm 0.8$ \\
5-Formyl-FH & 10.3 & $2.5 \pm 0.8$ \\
5-Methyl-FH & 12.3 & $7.3 \pm 1.6$ \\
Total & 36 & $20.3 \pm 2.1$
\end{tabular}

The myeloid precursor cells were preincubated for $24 \mathrm{~h}$ in folate-free RPMI-1640 supplemented by $5 \times 10^{-8} \mathrm{M}\left[{ }^{3} \mathrm{H}\right]$ folinic acid. After extraction and conjugase treatment of the extract, the sample was concentrated with a $\mathrm{C}_{18}$ Sep-Pak (see Methods). A 100- $\mu$ l aliquot of the $\mathrm{C}_{18}$ Sep-Pak extract was counted for total folate content, and the remainder of the sample was assayed for individual folates by HPLC. Each value represents the mean \pm SEM of seven separate experiments. Background counts in the HPLC eluate averaged $50 \mathrm{dpm}$, while the folate cofactor peaks were $50-300 \mathrm{dpm}$ over background in a typical experiment.

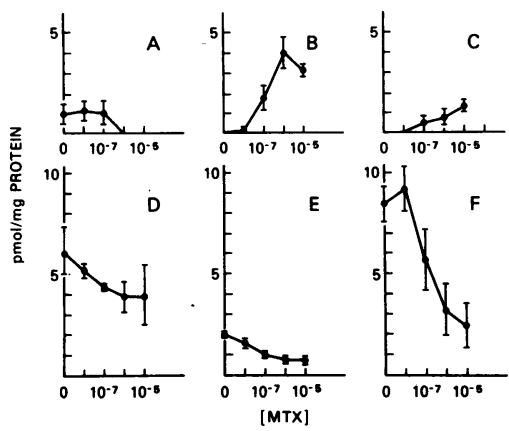

Figure 1. Effect of MTX on intracellular folate pools in MPCs from human marrow. MPCs of normal human marrow were preincubated with $5 \times 10^{-8} \mathrm{M}\left[{ }^{3} \mathrm{H}\right] 5$-formyl-FH $\mathrm{F}_{4}$ for $24 \mathrm{~h}$. MTX was then added to achieve a concentration of $10^{-8}-10^{-5} \mathrm{M}$ and incubation was continued for $2 \mathrm{~h}$. The folates were extracted and analyzed on HPLC as described in Methods. $(A) \mathrm{FH}_{4}$; (B) $\mathrm{FH}_{2} ;(C)$ 10-formyl- $\mathrm{FH}_{2} ;(D)$ 10-formyl- $\mathrm{FH}_{4} ;(E)$ 5-formyl- $\mathrm{FH}_{4}$;

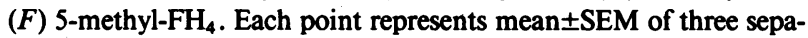
rate experiments.

cells, decreased to $14 \%$ of the total folates in the presence of 1 $\mu \mathrm{M}$ MTX for $4 \mathrm{~h}$.

We next examined the time course of the intracellular folate changes after exposure to $1 \mu \mathrm{M}$ MTX (Fig. 2). The main effects, a rapid decrease in the 5-methyl-FH $\mathrm{FH}_{4}$ (Fig. $2 \mathrm{~F}$ ) and a reciprocal

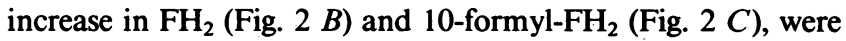
measurable after $2 \mathrm{~h}$ of exposure, with little further change after $12 \mathrm{~h}$ of incubation with MTX. There was a $38 \%$ decrease in $10-$ formyl- $\mathrm{FH}_{4}$ at $2 \mathrm{~h}$, but no further reduction at later time points.

To correlate these changes with the effect of MTX on the rate of de novo purine synthesis, MPCs, $1 \times 10^{6}$ cells per sample, were incubated for 2 and $4 \mathrm{~h}$ with $1 \mu \mathrm{M}$ MTX and labeled with $\left[{ }^{14} \mathrm{C}\right]$ glycine. The $\left[{ }^{14} \mathrm{C}\right]$ glycine incorporation decreased to $40 \pm 7 \%$ of the control after $2 \mathrm{~h}$ of MTX and to $23 \pm 10 \%$ after $4 \mathrm{~h}$ of MTX exposure, despite the fact that the folate cofactor for purine biosynthesis, 10 -formyl-FH $\mathrm{F}_{4}$, decreased by only $38 \%$ at $2 \mathrm{~h}$, and remained at this concentration thereafter.

Cytotoxic effect of MTX on CFU-C. To verify that the conditions used in these experiments were cytotoxic to myeloid cells, $2 \times 10^{5}$ MPCs in sample, were incubated with 0.001-10 $\mu \mathrm{M}$ MTX for $12 \mathrm{~h}$ and the ability of these cells to form colonies was assessed. A decrease of $24 \%$ in CFU-Cs was observed after 0.1 $\mu \mathrm{M}$ MTX for $12 \mathrm{~h}, 64 \%$ after $1 \mu \mathrm{M}$ MTX, and $84 \%$ after 10

Table II. MTX Concentration Effect on the Total Folate Content in Myeloid Precursor Cells

\begin{tabular}{cl}
\hline MTX & Total folates \\
\hline$\mu M$ & pmol/mg protein \\
0 & $17.5 \pm 1.4$ \\
0.01 & $17.2 \pm 1.4$ \\
0.1 & $14.4 \pm 1.7$ \\
1.0 & $12.5 \pm 0.8$ \\
10 & $11.4 \pm 1.5$
\end{tabular}

MPCs were preincubated for $24 \mathrm{~h}$ in folate-free RPMI-1640 supplemented by $5 \times 10^{-8} \mathrm{M}\left[{ }^{3} \mathrm{H}\right]$ folinic acid and exposed to indicated concentration of MTX for $2 \mathrm{~h}$. After washing in ice-cold PBS, the cells were processed as per the Methods section. The total radioactivity was measured in $100-\mu \mathrm{l}$ aliquots of each sample, and total folate content was calculated based on the specific activity of the labeled folates and the cytosol protein concentration. Each value represents the mean \pm SEM of three separate experiments. 

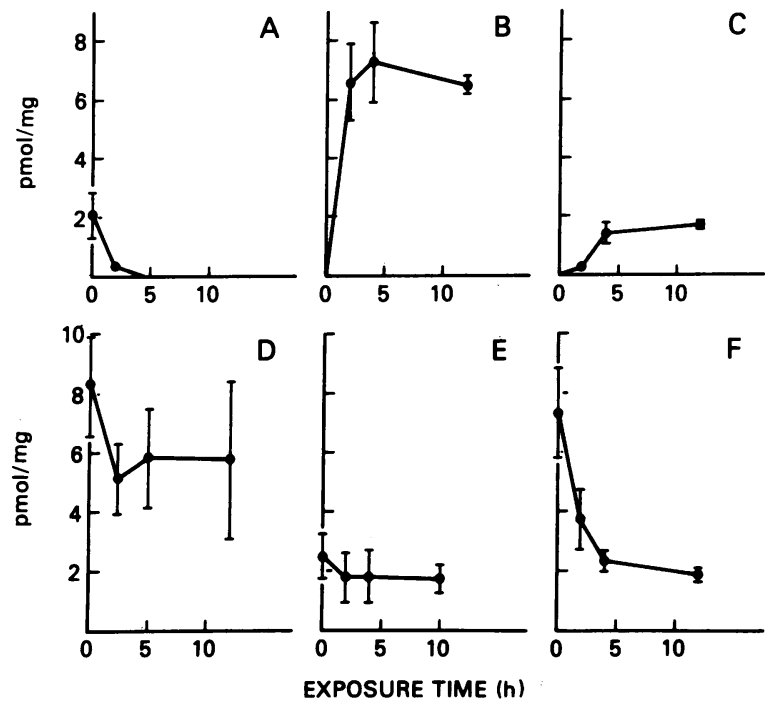

Figure 2. Effect of $1 \mu \mathrm{M}$ MTX on intracellular folate pools in MPCs of normal human marrow. MPCs of normal human marrow were preincubated with $5 \times 10^{-8} \mathrm{M}\left[{ }^{3} \mathrm{H}\right] 5-$ formyl- $\mathrm{FH}_{4}$ for $24 \mathrm{~h}$ and then exposed to $1 \mu \mathrm{M}$ MTX for 2,4 , and $12 \mathrm{~h}$. The folates were extracted and analyzed by HPLC. $(A) \mathrm{FH}_{4} ;(B) \mathrm{FH}_{2} ;(C)$ 10-formyl-FH $\mathrm{H}_{2} ;(D)$ 10-formyl- $\mathrm{FH}_{4} ;(E)$ 5-formyl- $\mathrm{FH}_{4} ;(F) 5$-methyl- $\mathrm{FH}_{4}$. Each point represents mean \pm SEM of seven separate experiments.

$\mu \mathrm{M}$ MTX. These changes parallel the expansion of the intracellular $\mathrm{FH}_{2}$ pool, which was $50 \%$ of its maximal value at 0.1 $\times 10^{-6} \mathrm{M}$ and was maximal at $1 \times 10^{-6} \mathrm{M}$ (Fig. 3).

The cytotoxic effect of MTX is attributed to its inhibitory effect on both the pyrimidine and purine synthesis. To determine that purine inhibition contributed to the cytotoxic effect of MTX, the cells were incubated for $12 \mathrm{~h}$ in the presence of $0.01-10 \mu \mathrm{M}$ concentrations of MTX and $10 \mu \mathrm{M}$ thymidine. The cells were washed and resuspended in drug-free and rescue-free medium before CFU-C assays. The addition of thymidine provided minimal protection, increasing the plating efficiency from 36 to $55 \%$ of the control in the presence of $1 \mu \mathrm{M}$ MTX and from 16 to $23 \%$ at $10 \mu \mathrm{M}$ MTX. A complete protection against MTX toxicity in these cells was achieved by incubation of cells with the combination of $10 \mu \mathrm{M}$ thymidine and $10 \mu \mathrm{M}$ deoxyinosine (15).

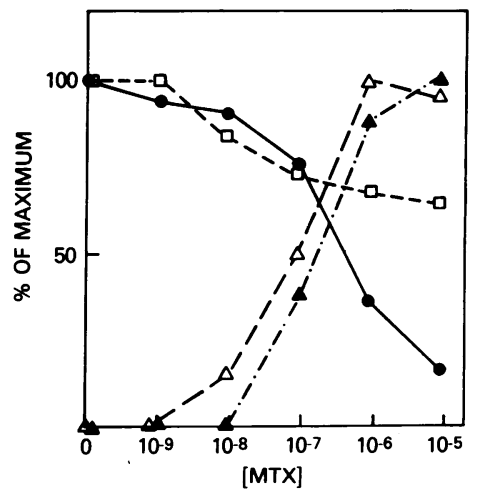

Figure 3. Relationship between MTX concentration, changes in intracellular folates, and cytotoxicity (See legends in Figs. 1 and 2). The quantitation of intracellular folates, as well as assay of myeloid colony formation, were performed as described in Methods after incubation with MTX at indicated concentrations for 12 h. CFU-Cs (solid circles) and 10 -formyl-FH 4 (open squares) are shown as per-

cent of control. $\mathrm{FH}_{2}$ (open triangles) and 10-formyl- $\mathrm{FH}_{2}$ (solid triangles) are expressed as percent of the highest measured level.

\section{Discussion}

The present studies provide for the first time an estimation of the intracellular folate distribution in human myeloid precursor cells. The primary intracellular folates in these cells, each comprising $\sim 40 \%$ of the total folate pool, were $5-$ methyl- $^{-} \mathrm{HH}_{4}$, which is readily converted to one of the active cofactor forms, and 10formyl- $\mathrm{FH}_{4}$, the required cofactor for de novo purine synthesis. Using these methods, we were unable to precisely measure intracellular levels of 5,10-methylene- $\mathrm{FH}_{4}$, the cofactor for thymidylate synthase and estimate that the concentration of this cofactor must be $<5 \%$ of the total folate pool in bone marrow myeloid precursor cells. Our estimate of the total folate pool, $20.3 \pm 2.1 \mathrm{pmol} / \mathrm{mg}$ cytoplasmic protein, is sevenfold higher than previous determinations of the folate content of unseparated bone marrow cells measured by microbiologic assay (19-21). The difference may be due to the higher folate content of immature cells; previous comparisons of leukemic myeloid cells versus normal leukeocytes revealed fivefold higher folate content in the blast cell population (22-24).

This assay was used to examine the changes in intracellular folates induced by MTX, an agent that inhibits DHFR and is believed to exert its effects by inhibition of DHFR and depletion of cellular reduced folates. MTX caused a rapid decrease in 5methyl- $\mathrm{FH}_{4}$ and depletion of $\mathrm{FH}_{4}$ to unmeasurable levels, but only a partial (30-40\%) decrease in the important cofactor 10formyl-FH4 . Thus, the biologically important 10 -formyl-FH $_{4}$ pool is conserved at the expense of 5-methyl-FH $\mathrm{F}_{4}$, a depot form of folate. The drug's inhibition of purine synthesis and that component of its toxicity related to purine deficiency thus could not be ascribed to depletion of 10 -formyl- $\mathrm{FH}_{4}$. Rather, inhibition of purine synthesis and CFU-C toxicity correlates with the marked expansion of the intracellular pool of $\mathrm{FH}_{2}$, a change that may contribute to MTX toxicity by direct inhibition of AICAR transformylase (5) and thymidylate synthase (3). At later time points, MTX polyglutamates that are formed in human myeloid cells, albeit in limited quantities compared with malignant cells (15), may contribute to the further direct inhibition of these enzymes. The intracellular $\mathrm{FH}_{2}$ concentration after $2 \mathrm{~h}$ exposure to 1 or $10 \mu \mathrm{M}$ MTX reached a plateau level of $7 \mathrm{pmol} /$ $\mathrm{mg}$ protein, or $\sim 1-2 \mu \mathrm{M}$. This concentration is on the orcier of magnitude required to inhibit AICAR transformylase $\left(K_{\mathrm{i}}=2.7\right.$ $\mu \mathrm{M})$ when facing pentagluatamated folate substrate (5). The degree of inhibition of the enzyme by $\mathrm{FH}_{2}$ will ultimately depend on the intracellular concentrations of $\mathrm{FH}_{2}$ and the substrate (10formyl- $\mathrm{FH}_{4}$ ) and the relative extent of polyglutamation of each.

It should be noted that the final cytotoxic effect of MTX is achieved through a collateral inhibition of purine as well as thymidylate synthesis. Only the purine arm of the MTX toxicity mechanism was examined in the present study.

The folate pool perturbations caused by MTX in normal myeloid precursors closely parallel the changes found in MCF7 breast cancer cells after MTX exposure (2). In this tumor cell line, the 10 -formyl- $\mathrm{FH}_{4}$ pool was only $20 \%$ diminished by 21 $h$ incubation with $1 \mu \mathrm{M}$ MTX, as compared with the $40 \%$ reduction in the normal myeloid precursors in the present study. Thus, in neither the normal cells nor the malignant cells does MTX cause quantitative depletion of this cofactor under cytotoxic conditions in tissue culture. Its selective action against malignant cells may relate to the more avid formation of MTX polyglutamates in sensitive malignant cells (25-31), because these forms of MTX markedly extend its intracellular half-life and 
contribute to direct inhibition of purine and thymidylate synthesis.

The accumulation of 10 -formyl- $\mathrm{FH}_{2}$ during MTX exposure bears a comment. The occurrence of this folate was previously reported in MCF-7 breast cancer cells treated by MTX, and it was suggested that 10 -formyl- $\mathrm{FH}_{2}$ might be generated through metabolic conversion from $\mathrm{FH}_{2}(2)$. The physiologic and pharmacologic actions of this folate are currently under investigation.

In addition to the effect of MTX on the intracellular distribution of folates, the drug caused a depletion of total intracellular folate levels, reaching a maximum reduction of $35 \%$ at $10 \mu \mathrm{M}$ MTX. The mechanism of this depletion is uncertain but may be caused by the heteroexchange mechanism described by Goldman (32). At least one of the three cellular efflux pumps for folate is coupled to the influx mechanism. Movement of MTX molecules into the cell by this pump would drive out an intracellular folate molecule or another anion that shares the pump. Consistent with this possibility was the finding of a disproportionate decrease in the intracellular concentration of monoglutamated folates, the most readily transported fraction of the intracellular folate pool, from 20 to $14 \%$ of total folate after 4-h exposure to $1 \mu \mathrm{M}$ MTX.

The distribution of intracellular folates found in myeloid precursor cells resembles that found in intestinal mucosa, but differs from that of nondividing tissue. According to microbial assays, 5-methyl- $\mathrm{FH}_{4}$ is the primary folate found in nondividing tissues such as liver $(8,33-35)$, kidney (33), or red blood cells (36). In contrast, the predominant folate in rapidly growing tumor cells is 10 -formyl- $\mathrm{FH}_{4}(34,37,38)$, the required cofactor for the AICAR transformylase and glycinamide ribonucleotide (GAR) transformylase reactions in the purine synthetic pathway. These two folate forms (5-methyl- $\mathrm{FH}_{4}$ and 10 -formyl- $\mathrm{FH}_{4}$ ) are present in equal concentrations in intestinal mucosa (34) and, according to the present study, in the immature myeloid fraction of normal marrow, indicating the intermediate proliferative potential of the cell fractions used in these experiments. It is possible that a more highly purified myeloblast fraction would contain higher levels of 10-formyl-FH . $_{4}$

\section{Acknowledgments}

We thank Dr. James Griffin (Dana-Farber Cancer Institute, Boston, MA) for providing the MY8 monoclonal antibody, Dr. Thalia Papayannopoulou (University of Washington, Seattle, WA) for providing the EP1 antibody, Dr. D. W. Golde (UCLA School of Medicine, Los Angeles, CA) for providing the MO colony-stimulating factor, and Kathy Moore for preparation of the manuscript.

\section{References}

1. Chabner, B. A. 1982. Methotrexate. In Pharmacologic Principles of Cancer Treatment. B. A. Chabner, editor. W. B. Saunders Co., Philadelphia, PA. 229-255.

2. Allegra, C. J., R. L. Fine, J. C. Drake, and B. A. Chabner. 1986. The effect of methotrexate on intracellular folate pools in human MCF7 breast cancer cells: evidence for direct inhibition of purine metabolism. J. Biol. Chem. 261:6478-6485.

3. Dolnick, B. J., and Y. Cheng. 1978. Human thymidylate synthetase. II. Derivatives of pteroylmono and polyglutamates as substrates and inhibitors. J. Biol. Chem. 253:3563-3567.

4. Allegra, C. J., B. A. Chabner, J. C. Drake, R. Lutz, D. Rodbard, and J. Jolivet. 1985. Enhanced inhibition of thymidylate synthetase by methotrexate polyglutamates. J. Biol. Chem. 260:9720-9726.
5. Allegra, C. J., J. C. Drake, J. Jolivet, and B. A. Chabner. 1985. Inhibition of phosphoribosylaminoimidazolecarboxamide transformylase by methotrexate and dihydrofolic acid polyglutamates. Proc. Natl. Acad. Sci. USA. 82:4881-4885.

6. Goldman, I. D., W. S. Lichtenstein, and V. T. Oliverio. 1968. Carrier-mediated transport of the folic acid analogue methotrexate in the L1210 leukemia cell. J. Biol. Chem. 243:5007-5017.

7. Moran, R. G., and P. D. Colman. 1982. A simple procedure for the synthesis of high specific activity tritiated (6S)-5-formyltetrahydrofolate. Anal. Biochem. 122:70-78.

8. McMartin, K. E., N. V. Nirayotha, and T. R. Tephly. 1981. Highpressure liquid chromatography separation and determination of rat liver folates. Arch. Biochem. Biophys. 209:127-136.

9. Golde, D. W., S. G. Quan, and M. J. Cline. 1978. Human Tlymphocyte cell line producing colony stimulatory activity. Blood. 52: 1068-1072.

10. Saxon, A., R. H. Stevens, and D. W. Golde. 1978. T-lymphocyte variant of hairy-cell leukemia. Ann. Intern. Med. 88:323-326.

11. Griffin, J. D., J. Ritz, L. M. Nadler, and S. F. Schlossman. 1981. Expression of myeloid differentiation antigens on normal and malignant myeloid cells. J. Clin. Invest. 68:932-941.

12. Griffin, J. D., R. P. Beveridge, and S. F. Schlossman. 1982. isolation of myeloid progenitor cells from peripheral blood of chronic myelogenous leukemia patients. Blood. 60:30-37.

13. Yokochi, T., M. Brice, P. S. Rabinovitch, T. Papayannopoulou, and G. Stamatoyannopoulou. 1984. Monoclonal antibodies detecting antigenic determinants with restricted expression in erythroic cells, from the erythroid committed progenitor level to the mature erythroblast. Blood. 63:1376-1384.

14. Koizumi, S., R. L. Fine, G. A. Curt, J. D. Griffin, and B. A. Chabner. 1985. Enrichment of myeloid progenitor cells from normal human bone marrow using an immune-rosette technique. Exp. Hematol. 13:560-565.

15. Koizumi, S., G. A. Curt, R. L. Fine, J. D. Griffin, and B. A. Chabner. 1985. Formation of methotrexate polyglutamates in purified myeloid precursor cells from normal human bone marrow. J. Clin. Invest. 75:1008-1014.

16. Bradford, M. M. 1976. A rapid and sensitive method for the quantitation of microgram quantities of protein using the principle of protein-dye binding. Anal. Biochem. 72:248-254.

17. Pike, B. L., and W. A. Robinson. 1976. Human bone marrow colony growth in agar-gel. J. Cell Physiol. 76:77-84.

18. Cadman, E., C. Benz, R. Heimer, and J. O’Shaughnessy. 1981. Effect of de novo purine synthesis inhibitors on 5-fluorouracil metabolism and cytotoxicity. Biochem. Pharmacol. 30:2469-2472.

19. Cox, E. V., D. M. Mathiews, M. J. Maynell, W. T. Cooke, and R. Gaddie. 1960. Cyanocobalamin, ascorbic acid and pteroylglutamates in normal and megaloblastic bone marrow. Blood. 15:376-380.

20. Cooke, W. T., E. V. Cox, R. Gaddie, D. M. Mathiews, and M. J. Maynell. 1959. The vitamin $B_{12}$, folic acid and ascorbic acid content of human bone marrow cells. J. Physiol. 145:35-36.

21. Trubowitz, S., O. Frank, and H. Baker. 1974. Survey of vitamin $B_{12}$ and folate in the serum and bone marrow tissue of hospitalized patients. Am. J. Clin. Nutr. 27:580-583.

22. Swendreid, M. E., F. M. Bethell, and O. D. Bird. 1951. The concentration of folic acid in leukocytes. Observations on normal subjects and persons with leukemia. Cancer Res. 11:864-867.

23. Hoffbrand, A. V., and B. F. A. Newcombe. 1967. Leucocyte folate in vitamin $\mathrm{B}_{12}$ and folate efficiency and in leukemia. Br. J. Haematol. 13:954-966.

24. Lavore, A., E. Tripp, K. Parsa, and A. V. Hoffbrand. 1975. Polyglutamate forms of folate in resting and proliferating mammalian tissues. Clin. Sci. Mol. Med. 48:67-73.

25. Fry, D. W., L. A. Anderson, M. Borst, and I. D. Goldman. 1983. Analysis of the role of membrane transport and polyglutamation of methotrexate in gut and the Ehrlich tumor in vivo as factors in drug sensitivity and selectivity. Cancer Res. 43:1087-1092.

26. Poser, R. G., F. M. Sirotnak, and P. L. Chello. 1981. Differential 
synthesis of methotrexate polyglutamates in normal proliferative and neoplastic mouse tissues in vivo. Cancer Res. 41:4441-4446.

27. Fabre, I., G. Fabre, and I. D. Goldman. 1984. Polyglutamation, an important element in methotrexate cytotoxicity and selectivity in tumor versus murine granulocytic progenitor cells in vitro. Cancer Res. 44:3190-3195.

28. Jolivet, J., and R. L. Schilsky. 1981. High-pressure liquid chromatography analysis of methotrexate polyglutamates in cultured human breast cancer cells. Biochem. Pharmacol. 30:1387-1390.

29. Jolivet, J., R. L. Schilsky, B. D. Bailey, J. C. Drake, and B. A. Chabner. 1982. Synthesis, retention, and biological activity of methotrexate polyglutamates in cultured human breast cancer cells. J. Clin. Invest. 70:351-360.

30. Jolivet, J., and B. A. Chabner. 1983. Intracellular pharmacokinetics of methotrexate polyglutamates in human breast cancer cells. Selective retention and less dissociable binding of 4- $\mathrm{NH}_{2}-10-\mathrm{CH}_{3}-$ Pteroglutamate ${ }_{4}$ and 4- $\mathrm{NH}_{2}-10-\mathrm{CH}_{3}-$ Pteroglutamate 5 to dihydrofolate reductase. J. Clin. Invest. 72:773-778.

31. Curt, G. A., J. Jolivet, B. D. Bailey, D. N. Carney, and B. A. Chabner. 1984. Synthesis and retention of methotrexate polyglutamates by human small-cell lung cancer. Biochem. Pharmacol. 33:1682-1685.
32. Goldman, I. D. 1971. A model system for the study of heteroexchange of diffusion: methotrexate-folate interactions in L1210 leukemia and Ehrlich ascites tumor cells. Biochim. Biophys. Acta. 233:624-634.

33. Duch, D. S., S. W. Bowers, and C. A. Nichol. 1983. Analysis of folate cofactor levels in tissues using high-performance liquid chromatography. Anal. Biochem. 130:385-392.

34. Sotobayashi, H., F. Rosen, and C. A. Nichol. 1966. Tetrahydrofolate cofactors in tissues sensitive and refractory to amethopterin. Biochemistry. 5:3878-3883.

35. Pheasant, A. E., J. Bates, J. A. Blair, and R. Nayyiz-Mazhir. 1983. Investigations of tissue folates in normal and malignant tissues. Br. J. Cancer 47:393-398.

36. Scott, J. M. 1976. The identification of the intracellular folate coenzymes of different cell types. Biochem. Soc. Trans. 4:845-850.

37. Yin, M. B., S. F. Zakrzowski, and M. T. Hayala. 1982. Relationship of cellular folate cofactor pools to the activity of 5-fluorouracil. Mol. Pharmacol. 23:190-197.

38. Silverman, M., L. W. Law, and B. Kaufman. 1961. The distribution of folic acid activities in lines of leukemic cells of the mouse. $J$. Biol. Chem. 236:2530-2533. 